\title{
Comparison of Leadership Levels of Students at the Faculty of Sport Sciences and Other Faculties
}

\author{
Tülin Atan, Şaban Ünver, Abdurrahim Kaplan, İzzet İslamoğlu *, Gül Demir \\ Faculty of Yasar Dogu Sports Sciences, Ondokuz Mayıs University, Samsun, Turkey \\ *Corresponding Author: izzetislamoglu@gmail.com
}

Copyright $\mathrm{O} 2018$ by authors, all rights reserved. Authors agree that this article remains permanently open access under the terms of the Creative Commons Attribution License 4.0 International License

\begin{abstract}
Leadership has a great significance in creating high performance and building team loyalty in sport. The purpose of this study is to compare the leadership levels of students studying at the Faculty of Sports Sciences and other faculties. In addition, leadership qualities were examined in terms of the variables of gender and place of stay. A total of 200 students studying at the Faculty of Sports Sciences ( $\mathrm{n}=100$; age $21.75 \pm 1.99$ years) and other faculties ( $\mathrm{n}=100$ age; $20.49 \pm 1.52$ years $)$ participated in this study voluntarily. "Leadership Orientations Questionnaire" developed by Bolman and Deal [1] and adapted into Turkish by Dereli [2] to assess the leadership qualities of students was used as data collection tool. In the sub-dimensions of structural, transformational and charismatic leadership, the scores of faculty of sport sciences students were found to be significantly higher than the scores of the students in other faculties $(p<0.01)$. The average scores of men were found to be higher than those of women in the sub-dimensions of transformational and charismatic leadership $(p<0.05)$. It was concluded that the students studying at the Faculty of Sport Sciences had higher leadership qualities, with men having better leadership qualities.
\end{abstract}

Keywords Leadership, Faculty of Sport, Sciences

\section{Introduction}

The word leader is used to mean "the person in charge of the top level management of an institution, chief, head" [3]. Krausz defined leadership as the type of power used in influencing other people's activities [4]. Leadership is not very good in one quality, but it is very good in all qualities and to integration with these qualities in a specific way with charisma [5]. Leadership and authority have changed from the day they have come to being until today and these changes have advanced to and good for integration charismatic leadership, which is the modern leadership concept. Charismatic leadership is a concept which becomes increasingly widespread [6]. Charisma is the ability to attract people and it is open to development through education [7]. Kayıkc1 [8] views leadership not as a position with an important role in the institution, but as a prestigious position. Employees view their leader as a motivating, leading person who orientates them to push their capacity. Sahin [9] states that, leaders do not only try to develop the environment, but they are also interested in psychological and social environment and leadership emphasizes interpersonal relations and has a direct effect on motivating.

Leadership has a great significance in creating high performance and building team loyalty in sport. Thus, the style of leadership chosen by the leader in sport significantly influences person's effectiveness as a leader. In return, whether the team will succeed depends on the leader's choosing the right kind of leadership. Choosing a suitable style of leadership and using suitable motivation techniques lead to the success of both individual and organizational purposes. In Counsinman's studies, it is stated that in sport, each coach has a style suitable for himself and what he has to do first is to achieve the love and respect of athletes [10]. In studies conducted on leadership in sport, it can be seen that coaches are grouped as autocratic, democratic and laissez-faire leadership styles according to their behavior structures [11].

This study examines whether there is difference between the leadership levels of students studying at the Faculty of Sport Sciences and other faculties.

\section{Material and Method}

A total of 200 students studying at the Faculty of Sports Sciences $(n=100)$ who had an average age of $21.75 \pm 1.99$ years and other faculties (Health Sciences, Engineering, Science and Letters, Education, Architecture, Economy and Agriculture) $(\mathrm{n}=100)$ who had an average age of 
$20.49 \pm 1.52$ years participated in this study voluntarily. Students studying at the Faculty of Sport Sciences and actively participating in sports to study the influence of sport on leadership are included.

\subsection{Data Collection Tool}

"Demographic Information Form" prepared by the researchers and "Leadership Orientations Questionnaire" developed by Bolman and Deal [1] and adapted into Turkish Dereli [2] to assess the leadership qualities of students were used as data collection tool in the study. The scale has a total of 32 items and it has four sub-dimensions of humanistic leadership, structural leadership, transformational leadership and charismatic leadership. Each sub-dimension includes 8 items; humanistic leadership (items 2, 6, 10, 14, 18, 22, 26 and 30), structural leadership (items 1, 5, 9, 13, 17, 21, 25 and 29), transformational leadership (items 3, 7, 11, 15, 19, 23, 27 and 31) and charismatic leadership (items 4, 8, 12, 16, 20, 24, 28 and 32). The 5-likert type scale is scored as "Never = 1 ", "Rarely $=2$ ", "Sometimes $=3$ ", "Frequently $=4$ and "Always $=5 "$. One can get at least 8 points and at most 40 points from each scale [2]. According to this, a high score from the dimensions of the scale shows that the person always displays the related leadership quality, while a low score shows that the person never displays the related leadership quality.

When Cronbach Alpha internal consistency coefficient values of the total and sub-dimensions of the scale were examined, total Cronbach Alpha was 0.93, humanistic dimension Cronbach Alpha was 0.86, structural dimension Cronbach Alpha was 0.87, transformational dimension Cronbach Alpha was 0.84 and charismatic dimension Cronbach Alpha was 0.86. The total and sub-dimension Cronbach Alpha values of the scale show that the study has internal consistency.

SPSS 21 program was used for the analysis of the data. Kolmogorov-Smirnov test was used to check whether the data were normally distributed and the data were not found to be normally distributed $(p<0,05)$. Descriptive statistics (average, standard deviation, median, minimum and maximum values) of the variables were conducted. Mann Whitney U and Kruskal Wallis test were used. The level of significance was taken as 0.05 , for comparison of three groups $0.05 / 3=0.0166$.

\section{Results}

Table 1. Leadership levels in terms of the faculties of the students

\begin{tabular}{|c|c|c|c|c|c|c|c|c|}
\hline $\begin{array}{c}\text { Sub-dimensions } \\
\text { of leadership }\end{array}$ & Faculty & $\mathrm{N}$ & Mean & SS & Median & Min & $\operatorname{Max}$ & $\mathrm{P}$ \\
\hline \multirow[t]{2}{*}{ Humanistic } & $\begin{array}{c}\text { Sports } \\
\text { Sciences }\end{array}$ & 100 & 32.54 & 4.79 & 33.00 & 15 & 40 & \multirow[t]{2}{*}{.433} \\
\hline & Other & 100 & 31.94 & 5.11 & 32.00 & 9 & 40 & \\
\hline \multirow[t]{2}{*}{ Structural } & $\begin{array}{c}\text { Sports } \\
\text { Sciences }\end{array}$ & 100 & 31.67 & 5.12 & 32.00 & 16 & 40 & \multirow[t]{2}{*}{.001} \\
\hline & Other & 100 & 29.35 & 5,02 & 30.00 & 9 & 39 & \\
\hline \multirow[t]{2}{*}{ Transformational } & $\begin{array}{c}\text { Sports } \\
\text { Sciences }\end{array}$ & 100 & 30.41 & 5.34 & 30.00 & 14 & 40 & \multirow[t]{2}{*}{.000} \\
\hline & Other & 100 & 26.84 & 5.70 & 27.00 & 9 & 40 & \\
\hline \multirow[t]{2}{*}{ Charismatic } & $\begin{array}{c}\text { Sports } \\
\text { Sciences } \\
\end{array}$ & 100 & 30.75 & 5.22 & 31.00 & 14 & 40 & \multirow[t]{2}{*}{.000} \\
\hline & Other & 100 & 27.29 & 5.95 & 28.00 & 8 & 40 & \\
\hline
\end{tabular}

Table 1 compares the leadership scale sub-dimensions in terms of the variable of faculty. In the sub-dimensions of structural, transformational and charismatic leadership, the scores of faculty of sport sciences students were found to be significantly higher than the scores of the students in other faculties $(\mathrm{p}<0.01)$. However, no significant difference was found in the humanistic leadership sub-dimension in terms of faculty $(\mathrm{p}>0.05)$.

Table 2. Leadership levels in terms of gender

\begin{tabular}{|c|c|c|c|c|c|c|c|c|}
\hline $\begin{array}{c}\text { Sub-dimensions } \\
\text { of leadership }\end{array}$ & Faculty & $\mathrm{N}$ & Mean & SS & Median & Min & Max & $\mathrm{P}$ \\
\hline \multirow{2}{*}{ Humanistic } & Men & 96 & 32.01 & 5.47 & 33.00 & 9 & 40 & \multirow{2}{*}{.844} \\
\hline & Women & 104 & 32.45 & 4.44 & 32.00 & 15 & 40 & \\
\hline \multirow{2}{*}{ Structural } & Men & 96 & 30.84 & 5.71 & 32.00 & 9 & 40 & \multirow{2}{*}{.137} \\
\hline & Women & 104 & 30.20 & 4.67 & 30.00 & 17 & 40 & \\
\hline \multirow{2}{*}{ Transformational } & Men & 96 & 29.73 & 5.60 & 30.00 & 12 & 40 & \multirow{2}{*}{.006} \\
\hline & Women & 104 & 27.59 & 5.80 & 28.00 & 9 & 40 & \\
\hline \multirow{2}{*}{ Charismatic } & Men & 96 & 30.27 & 5.68 & 31.00 & 8 & 40 & \multirow{2}{*}{$.002 *$} \\
\hline & Women & 104 & 27.86 & 5.78 & 28.00 & 10 & 40 & \\
\hline
\end{tabular}

When Table 2 was examined, it was found that the average scores of men were found to be higher than those of women in the sub-dimensions of transformational and charismatic leadership $(p<0.05)$. However, no significant difference was found in the sub-dimensions of humanistic and structural leadership in terms of gender $(\mathrm{p}>0.05)$. 
Table 3. Leadership levels in terms of place of stay

\begin{tabular}{|c|c|c|c|c|c|c|c|c|}
\hline Sub-dimensions of leadership & Place of stay & $\mathrm{N}$ & Mean & SS & Median & Min & Max & $\mathbf{P}$ \\
\hline \multirow{3}{*}{ Humanistic } & Dormitory & 91 & 32.38 & 4.74 & 32.00 & 15 & 40 & \multirow{3}{*}{.695} \\
\hline & Hausemate & 61 & 32.37 & 5.53 & 33.00 & 9 & 40 & \\
\hline & Family & 48 & 31.79 & 4.62 & 32.00 & 15 & 39 & \\
\hline \multirow{3}{*}{ Structural } & Dormitory & 91 & 30.65 & 4.88 & 30.00 & 16 & 39 & \multirow{3}{*}{.699} \\
\hline & Hausemate & 61 & 30.72 & 5.63 & 32.00 & 9 & 40 & \\
\hline & Family & 48 & 29.95 & 5.26 & 31.00 & 16 & 40 & \\
\hline \multirow{3}{*}{ Transformational } & Dormitory & 91 & 28.18 & 5.75 & 29.00 & 15 & 40 & \multirow{3}{*}{.602} \\
\hline & Hausemate & 61 & 29.04 & 5.83 & 29.00 & 12 & 40 & \\
\hline & Family & 48 & 28.91 & 5.88 & 29.50 & 9 & 40 & \\
\hline \multirow{3}{*}{ Charismatic } & Dormitory & 91 & 28.49 & 5.75 & 29.00 & 11 & 40 & \multirow{3}{*}{.061} \\
\hline & Hausemate & 61 & 30.31 & 6.05 & 31.00 & 8 & 40 & \\
\hline & Family & 48 & 28.37 & 5.62 & 28.00 & 10 & 40 & \\
\hline
\end{tabular}

Table 3 compares leadership scale sub-dimensions in terms of the variable of place of stay (in a house with friends, with family, in a dormitory). No significant difference was found in the sub-dimensions of leadership in terms of the variable of place of stay $(p>0.05)$.

\section{Discussion}

Our study examines the leadership levels of students studying at the Faculty of Sports Sciences and other faculties. In terms of the sub-dimensions of the leadership scale, students of the faculty of sport sciences were found to have higher scores than the scores of other faculties' students in terms of "structural", "transformational" and "charismatic" leadership sub-dimensions. However, it was found that in the sub-dimension of "humanistic leadership", leadership level did not differ in terms of faculties. This result shows that athletes have higher leadership qualities, that is, it can be said that sport increases leadership qualities.

The fact that people who do sports get in social environments more strengthens their will and helps them to gain self-confidence and find out their unexplored aspects. Thus, one can earn other people's trust and this can influence the formation of creative and leadership qualities. As a conclusion, sport can be effective in individual's earning leadership qualities which include that knowing the responsibilities of the self and the society one is a member of, being positive, creative, competitive, productive, moral, virtuous, strong, dignified, farsighted, charismatic and humane [12].

In some studies in literature, studies which support our views were found. Yücel [13] examined whether the transformational leadership scores differs significantly in terms of the variable of doing any sport. Transformational leadership scores of students who did sports were found to be higher than the scores of students who did not do any sport. In his study, Güngör [14] found that leadership qualities of 115 prospective physical training teachers who were actively interested in sports were found to be slightly higher than those of 139 prospective teachers who were not actively interested in sports; however, this difference was not found to be statistically significant. In his study, Özdenk [15] found that the transformational leadership averages of athletes who did individual sports were found to be higher than those who did not do sports. In another study, it was found that sport is effective in earning leadership qualities, which is one of the social factors [16].

There are also studies in literature which are not in parallel with our study. Başoğlu [17] concluded that for leadership dimensions, the variable of pre-military school sportive state was not very significant. The reason why the results of our study and Başoğlu's study are different can be because leadership qualities were compared in terms of the state of doing active sport in our study and doing sport before entering military high school in Başoğlu's [17] study. In Özdenk [15]'s study, it was found that the average scores of students who did not do sport were found to be higher than students who did sport in terms of the sub-dimension of "structural leadership".

Our study examined whether gender had an influence on leadership levels. In the sub-dimensions of "transformational" and "charismatic" leadership, men were found to have higher scores than women. However, no significant difference was found in "humanistic" and "structural" leadership sub-dimensions in terms of gender.

It has been said that charismatic leaders are different from ordinary people, they have superior power and privilege different from ordinary men [18]. Male-dominant society predicts men to be superior all the time and this structure is accepted most of the time by women in male dominant society. This state can explain why men have more charismatic leadership qualities than women in our 
study (http://www.altinmiras.com). In Efekan's study [19], male students were found to have higher charismatic leadership scores when compared with female students. In our study, it was found that male athletes show more "transformational" leadership quality which included restructuring in necessary changes of time, being creative and open to trials.

Transformational leadership is the process of influencing spectators' feelings with interest and characteristics by using charismatic skills and enabling the spectators to be motivated in the maximum level possible [20]. The fact that men had more charismatic leadership qualities in our study can have influenced transformational leadership as well. In his study, Y1lmaz [21] stated that there were no differences between the transformative leadership levels of male executives and female executives. The average age of the subjects in this study were found to be greater than the average age of the subjects in our study. This can be the reason for the different result in our study.

In our study, "humanistic" and "structural" leadership levels were not found to differ between two genders. Studies were found to support this result of our study. In Semiz's [22] study on the leadership orientation of secondary school students, no significant difference was found in terms of the variable of gender. In Çar's [23] study on the leadership orientation of university students, no significant difference was found in terms of the variable of gender.

In our study, students' leadership scale sub-dimensions were examined as regards the variable of place of stay (in a house with friends, with family, in a dormitory) and leadership orientation sub scores were not found to differ. In a study, when differences between the leadership orientation scales of university students were examined in terms of the variable of place of stay, no significant difference was found [23].

As a conclusion the students studying at the Faculty of Sports Sciences had higher leadership qualities. Besides, males had some better leadership qualities than females.

\section{REFERENCES}

[1] Bolman, L.G., and Deal, T.E. (1991). Reframing organizations. Artistry, choice and leadership, San Francisco: Jossey-Bass.

[2] Dereli, M. (2003). İlköğretim okulu müdürlerinin liderlik davranışları. Yüksek Lisans Tezi, Orta Doğu Teknik Üniversitesi Eğitim Bilimleri Enstitüsü, Ankara.

[3] Yüksel, M. M. (2006). Karizmatik Lider Örneği Olarak Hz. Ömer. Yüksek Lisans Tezi, Selçuk Üniversitesi Sosyal Bilimler Enstitüsü, Konya.

[4] Arıkan, S. (2001). Yönetim ve Organizasyon, Ankara: Nobel Yayınc1lı. 1. Bask1 s.12-35.

[5] Baykal, A.N. (2000). Mustafa Kemal Atatürk'ün liderlik sırları, İstanbul: Sistem Yayıncılık, 11.Basın.

[6] Kilınç, T. (1996). Liderlikte Durumsallığın Ötesi (II): Karizmatik Liderlik Yaklașımı. İstanbul Üniversitesi İşletme Fakültesi Dergisi, 25(2).

[7] Maxwell, C. (1999). Liderlik Nitelikleri: Reddedilmez 21 Liderlik Niteliği. (Çeviren: İbrahim Şener). İstanbul: Beyaz Yayınları.

[8] Kayıkçı, K. (1999). Toplam Kalite Yönetiminde Liderlik. Kuram ve Uygulamada Eğitim Yönetimi Dergisi. 5(20), $1-19$.

[9] Şahin, M. (1998). Spor Ahlakı ve Sorunları, Evrensel Basımevi, Ankara.

[10] Koç, S. (1994). Spor psikolojisine giriş. Saray Kitapevleri. İzmir.

[11] Martens, R. (1987). Coaches Guide to Sport Psychology, Illinois: Human Kinetics Publishers.

[12] Yetim AA. 2000. Sporun sosyal görünümü. Gazi Beden Eğitimi ve Spor Bilimleri Dergisi (Gazi BESBD).

[13] Yücel, Y. (2011). Orta Öğretim (Lise) Kurumlarında Eğitim Gören, Spor Yapan ve Yapmayan Öğrencilerin Liderlik Özelliklerinin Araştırılması. Yüksek Lisans Tezi. Erciyes Üniversitesi Sosyal Bilimler Enstitüsü, Kayseri.

[14] Güngör, N.B. (2016). Beden Eğitimi Öğretmen Adaylarının Epistemolojik İnançları ile Liderlik Özellikleri Arasındaki İlişkinin İncelenmesi. Yüksek Lisans Tezi. Ankara.

[15] Özdenk, S. (2015). Bireysel ve takım sporuyla uğraşan sporcular ile spor yapmayan bireylerin duygusal zeka ve liderlik özelliklerinin incelenmesi. Doktora Tezi, Gazi Üniversitesi Eğitim Bilimleri Enstitüsü. Ankara.

[16] Çoban, B., Coşkuner, Z. (2006). Sporda Grup Dinamiği ve Liderlik, Ankara, Nobel Yayın.

[17] Başoğlu U. (2006). The leadership characteristics of military high school students concerning the sport activities they are making: Individual sports, team sports or none. Unpublished master's thesis. Marmara University Institute of Health Sciences, İstanbul.

[18] Baltaş A. (2005). Ekip çalışması ve liderlik. Remzi, İstanbul, 2005.

[19] Efekan, H. (2007). Kara Harp Okulu Olimpik Spor Branşlarında Yapılan Bireysel Sporlar ile Takım Sporlarının Harbiyeli'lerin Liderlik Özelliklerine Sağladığı Etkilerin İncelenmesi, Yüksek Lisans Tezi, Gazi Üniversitesi Sağlık Bilimleri Enstitüsü, Ankara.

[20] Maral, M. (2016). Okul Yöneticilerinin Liderlik Stilleri ile Çatışma Çözme Stratejiri Arasındaki İlişki. Yüksek Lisans Tezi. Sakarya.

[21] Yilmaz, R. (2016). Yöneticilerin Dönüștürücü Liderlik Düzeylerinin Psikolojik İyi Oluş ve Bazı Değişkenlere Göre Yordanması. Yüksek Lisansa Tezi. İstanbul.

[22] Semiz, H. (2011). Effect of high school students in sports leadership (Hendek example). Unpublished master's thesis. Sakarya University Institute of Education Sciences, Sakarya.

[23] Çar, B. (2013). Spor eğitimi alan üniversite öğrencilerinin liderlik özelliklerinin belirlenmesi. Yüksek Lisans Tezi. Gazi Üniversitesi Eğitim Bilimleri Enstitüsü, Ankara. 